\title{
PROBLEMATIKA PENERAPAN AKUNTANSI PEMBIAYAAN MUDHARABAH PADA PERBANKAN SYARIAH
}

\section{Problematics In Implementation Of Financial Accounting Mudharabah On Syariah Banking}

\author{
Raodahtul Jannah \\ Email : raodahtul.jannah@uin-alauddin.ac.id \\ Prodi Akuntansi \\ Universitas Islam Negeri Alauddin Makassar \\ Risa Rukmana \\ Email : risarukmana@gmail.com \\ Prodi Akuntansi \\ STIE Tri Dharma Nusantara \\ Nurhidayah, \\ Email: nurhidayah@unsulbar.ac.id \\ Prodi Akuntansi \\ Universitas Sulawesi Barat
}

\begin{abstract}
ABSTRAK
Penelitian ini merupakan artikel konseptual yang menggunakan metode library research (kepustakaan) dengan tujuan untuk mengkaji problematika yang terjadi pada penerapan pembiayaan mudharabah pada Perbankan Syariah. Pembiayaan mudharabah adalah bentuk kerja sama antara dua pihak atau lebih, yang mana pemilik modal (shahibul maal) memberikan sejumlah modal kepada pengelola (mudharib) untuk menjalankan usaha dengan kesepakatan untung rugi akan dibagi bersama sesuai dengan porsi yang telah disepakati pada saat akad. Pembiayaan mudharabah menjadi produk yang ideal dan paling tepat dikembangkan pada Perbankan Syariah yang sesuai dengan tujuan ekonomi islam. Walaupun ada beberapa tantangan atau risiko yang harus dihadapi dalam implementasinya dilapangan diantaranya yaitu permasalahan asimetri informasi serta moral hazard. Salah satu upaya untuk mengurangi permasalahan dari penerapan akad pembiayaan mudharabah dengan menentukan syarat-syarat yang harus dipatuhi oleh nasabah.
\end{abstract}

Kata Kunci : Pembiayaan mudharabah, Perbankan syariah, resiko

\section{ABSTRACT}

This research is a conceptual article that uses the library research method (literature) with the aim of examining the problems that occur in the implementation of mudharabah financing in Islamic Banking.Mudharabah financing is a form of cooperation between two or more parties, in which the owner of capital (shahibul maal) provides a sum of capital to the manager (mudharib) to run a business with a profit and loss agreement that will be shared according to the portion agreed upon at the time of the contract. Mudharabah financing is an ideal and most appropriate 
product to be developed in Islamic Banking in accordance with the objectives of Islamic economics. Although there are several challenges or risk that must be faced in its implementation in the field, including the problem of information asymmetry and moral hazard. One of the efforts to reduce problems from implementing a mudharabah financing contract is by determining the conditions that must be obeyed by the customer.

Keywords : Mudharabah Financing, Islamic Banking, Risk

\section{PENDAHULUAN}

Pada masa sekarang ini, salah satu kegiatan operasional perbankan dalam memenuhi kebutuhan manusia telah menggunakan system keuangan dengan prinsip pemberian modal (equity financing) dan prinsip pemberian pinjaman melalui pembiayaan (debt financing) yang diperoleh dari proses penghimpunan dana pihak ketiga dalam hal ini masyarakat. Menurut Bambang (2016) Metode pemenuhan kebutuhan manusia yang diterapkan dalam perbankan syariah menggunakan akad system bagi hasil (profit and loss sharing) untuk prinsip pemberian modal sedangkan untuk pemberian pembiayaan menggunakan akad jual beli (al-bai).

Sistem kerja yang berlaku pada perbankan syariah menggunakan pola system bagi hasil (Profit loss sharing) tanpa adanya unsur penambahan atau bunga seperti yang diterapkan pada bank-bank konvensional pada umumnya. Profit loss sharing yang diterapkan dalam perbankan syariah disini dalam artian bahwa keuntungan maupun kerugian yang timbul dari setiap transaksi itu sama-sama akan menjadi tanggungan antara kedua belah pihak. Hal ini lah yang akan menjadi dasar nantinya untuk kedua belah pihak untuk sama-sama memperhatikan prospek akan kemajuan ataupun kemunduran dari usaha yang telah dijalankan. Dalam perbankan syariah, produk-produk pembiayaan yang menggunkaan pola system bagi hasil (profit loss sharing) yang paling banyak diminati itu salah satunya adalah pembiayaan mudharabah.

Pembiayaan mudharabah diartikan sebagai salah satu akad kerja sama yang dilakukan antara pemilik modal (shahibul maal) dan pelaku usaha (mudharib) dengan mengamalkan nilai-nilai kejujuran,kepercayaan, dan saling sepakat terkait usaha apa yang dijalankan nantinya. (Sa'diyah, 2013:304). Pembiayaan mudharabah ini pada dasarnya membutuhkan biaya operasional yang tinggi dan memiliki banyak resiko yang muncul sehingga untuk mengaplikasikannya dilapangan itu cenderung tidak mudah. Berdasarkan data yang diterbitkan di web otoritas jasa keuangan (OJK) per Juni 2018 menunjukkan bahwa pangsa pasar untuk perbankan syariah itu diangka presentase 
5,70\% dimana ketika ditelusuri dari masing-masing skema pembiayaan yang diterpakan dalam perbankan syariah itu masih didominasi oleh akad murabahah dengan tingkat presentase 51,77\%, kemudian Musyarakah 36,86\%, akad Mudharabah 5,27\%, dan disusul akan ijarah hanya mencapai 3,18\%.

Ketika melihat data realisasi market share dari produk perbankan syariah diatas itu cenderung jauh dari upaya untuk menunjang kemajuan di bidang perekonomian, dimana kita mengharapkan produk pembiayaan dengan skema profit loss sharing yaitu mudharabah dan musyarakah yang harusnya memiliki presentase lebih tinggi dan paling banyak diimplementasikan di perbankan syariah. Karena seperti yang diketahui bahwa pola kerja dari system profit loss sharing ini menciptakan keseimbangan antara kedua belah pihak yakni pihak bank dan nasabah untuk saling berbagi baik itu keuntungan maupun resiko yang akan terjadi sehingga dapat memicu system investasi yang adil dan sehat.

Bisa jadi pihak perbankan syariah masih memiliki kekhawatiran dengan tingkat resiko yang muncul dari skema pembiayaan mudharabah dan musyarakah sehingga masih memperhatikan prinsip kehati-hatian ketika ingin menerapkan prodek pembiayaan tersebut. Hal ini mungkin salah satu yang memicu masih rendahnya tingkat pembiayaan mudharabah untuk diterapkan dalam dunia perbankan syariah. Selain itu, Menurut Abdullah Saeed (2008) bahwa pola system bagi hasil pada perbankan syariah yang diutarakan dalam teori itu ternyata susah untuk direalisasikan karena melihat pihak bank yang juga ikut serta dalam menanggung resiko dari pembiayaan tersebut sehingga dianggap tidak memberikan manfaat secara maksimal. Untuk itu, salah satu upaya yang dilakukan pihak bank syariah dengan memberikan batasan dari kemudahan pembiayaan mudharabah dengan mencoba mengubah mekanismenya dari system bagi hasil menjadi pembiayaan yang bebas resiko.

Melihat dari sisi para pelaku usaha mikro, pembiayaan mudharabah memberikan manfaat serta keuntungan dalam hal pemberian bagi hasil. Dimana mereka dapat membayar angsuran dari keuntungan bersih yang diperoleh setelah usaha yang dijalankannya selesai. Pembiayaan mudharabah merupakan salah satu pembiayaan yang ideal bagi para pelaku kegiatan usaha mikro karena pembiayaan dengan skema bagi hasil ini dapat memberikan keringanan dalam pembayaran angsuran karena pihak pemilik modal bisa menunggu dengan sabar sampai mudharib mampu membayar 
angsurannya meskipun usaha yang dijalankan sama sekali belum memperoleh keuntungan (Ernanda, 2018).

Berdasarkan pemaparan di atas, maka dapat disimpulkan bahwa untuk mendukung tercapainya tujuan ekonomi islam seharusnya dilakukan erbagai macam upaya yang bersifat inovatif dalam hal meningkkatkan porsi pembiayaan dengan skema bagi hasil yaitu pembiayaan mudharabah pada perbanksan syariah serta lembaga keuangan syariah lainnya. Untuk itu, adapun focus dari tujuan penulisan paper ini untuk mengetahui dan mengkaji problematika skema pembiayaan mudharabah dalam perbankan syariah sebagai metode keuangan Islam yang dianggap baik dalam perkembangan ekonomi islam kedepan..Serta memberikan solusi terkait upaya-upaya yang bisa dilakukan dalam mendorong pembiayaan bagi hasil menjadi nilai jual bisnis perbankan syariah.

\section{TINJAUAN PUSTAKA}

\section{Pembiayaan Mudharabah}

Asal istilah Mudharabah adalah berasal dari bahasa penduduk Irak yakni qiradh atau muqaradhah adalah bahasa dari penduduk Hijaz. Namun, pengertian qiradh dan mudharabah adalah sama (Suhendi, 2013). Mudharabah biasa disebut dengan qiradh yang berarti al-qath, yakni potongan. Kata mudharabah berasal dari akar kata dharaba pada kalimat al-dharbfi al-ardh, yakni bepergian untuk urusan dagang. Mudharabah adalah akad kerja sama antara bank syariah sebagai penyedia dana $100 \%$ (shahib al-mal) dengan nasabah atau pengusaha sebagai pengelola proyek (mudharib). Keuntungan proyek dibagi kepada kedua pihak sesuai dengan proporsi (nisbah) yang disepakati dalam perjanjian (Irma : 2011)

Mudharabah adalah mode yang penting untuk pembentukan dan pengoperasian institusi keuangan Islam serta berfungsi sebagai dasar bisnis yang dilakukan dengan menggabungkan dana dan keahlian dari kelompok orang yang berbeda-beda. Mudharabah ini dianggap sebagai aktivitas pembiayaan yang beresiko sangat tinggi terutama risiko moral, seleksi yang merugikan, dan kurangnya keahlian bank dalam penilaian proyek serta permasalahan teknis terkait. Bank syari'ah dapat menggunakan mudharabah walaupun dengan perhatian dan pengelolaan risiko yang tepat

Apabila usaha tersebut mengalami kegagalan, sehingga karena itu terjadi kerugian yang sampai mengakibatkan sebagian atau bahkan seluruh modal yang ditanamkan oleh shahib al-mal habis, maka yang menanggung kerugian keuangan hanya shahib al-mal sendiri, 
sedangkan mudharib sama sekali tidak menanggung atau tidak harus mengganti kerugian atas modal yang hilang, kecuali apabila kerugian tersebut terjadi sebagai akibat kecurangan yang dilakukan oleh mudharib.

Jadi dapat disimpulkan bahwa pembiayaan Mudharabah adalah akad kerjasama antara bank selaku pemilik dana (shahibul maal) dengan nasabah selaku (mudharib) yang mempunyai keahlian atau ketrampilan untuk mengelola suatu usaha yang produktif dan halal. Hasil keuntungan dari penggunaan dana tersebut dibagi bersama berdasarkan nisbah yang disepakati.

Rukun mudharabah terdiri dari pemodal, pengelola, modal, keuntungan, dan ijab qabul. Mudharabah merupakan salah satu metode transaksi keuangan yang beresiko tinggi. Dikarenakan sangat beisiko, bank konvensional saja tidak pernah berpikir untuk menetapkan metode seperti ini. Dalam prosesnya, diperlukan modal, pengelola, kemampuan pengelolaan serta manajemen yang baik untuk menjalankannya (Kettel, 2011).

Investasi dana di bank syari'ah menggunakan prinsip mudharabah. Jenis investasi dengan menggunakan skim mudharabah ini di bank syari'ah terbagi menjadi dua, yakni (Aziz, 2010):

\section{Mudharabah Mutlaqah (General Investment)}

Pada prinsipnya,mudharabah bersifat mutlak, dimana shahibul maal tidak menetapkan syarat-syarat tertentu kepada mudharib. Bentuk ini sering disebut dengan mudharabah muthlaqah, atau dalam bahasa Inggrisnya dikenal dengan URIA (Unrestricted Invesment Account) (A. A. Karim, 2010). Mudharabah Muthlaqah merupakan kerjasama antara dua pihak yang modalnya disediakan oleh shahibul maal (pemilik dana) dan kemudian dana tersebut dikelola penuh oleh mudharib (pihak yang menjalankan usaha). Keuntungan dan kerugian dibagi menurut kesepakatan di awal akad. Skim ini umumnya digunakan untuk deposito atau tabungan berjangka. Ciri khusus dari mudharabah jenis ini adalah nasabah tidak perlu menentukan kemana dananya akan diinvestasikan oleh bank syari'ah

2. Mudharabah Muqayyadah (Special Investment)

Merupakan kerjasama antara dua pihak yang shahibul maal menyediakan dana dengan memberikan kewenangan yang terbatas kepada pengelola usaha (mudharib). Skim ini biasanya digunakan untuk memfasilitasi 
kebutuhan nasabah yang pada umumnya adalah nasabah besar seperti perusahaan dan pemerintah untuk menggunakan bank syari'ah sebagai perpanjangan tangannya untuk berinvestasi pada sektor bisnis tertentu. Pada bank syari'ah, dana ini dikelola terpisah dari dana lainnya

\section{Perhitungan Nisbah Bagi Hasil}

Prinsip bagi hasil menurut Bank Indonesia adalah suatu prinsip pembagian laba yang diterapkan dalam kemitraan kerja, dimana porsi $m=$ bagi hasil ditentukan pada saat akad kerja sama. Dasar yang digunakan dalam perhitungan bagi hasil adalah berupa laba bersih usaha setelah dikurangi dengan biaya operasional. Menurut Karim (2006), penentuan nisbah didasarkan pada:

a. Prosentase, nisbah keuntungan yang harus dinyatakan dalam bentuk prosentase antara kedua belah pihak, bukan dinyatakan dalam nilai nominal.

b. Bagi Untung dan Bagi Rugi, ketentuan itu merupakan konsekuensi logis dari karakteristik akad mudharabah itu sendiri, yang tergolong kedalam kontrak investasi (natural uncertainty contracs). Dalam kontrak ini return tergantung kepada kinerja sektor riilnya, bila laba bisnisnya besar kedua belah pihak mendapat bagian yang besar pula akan tetapi bila labanya kecil maka bagiannya kecil juga, jadi filosofi ini hanya dapat berjalan jika nisbah laba ditentukan dalam bentuk prosentase, bukan dalam bentuk nominal.

c. Jaminan, tujuan pengenaan jaminan dalam akad mudharabah adalah untuk menghindari moral hazard mudharib bukan untuk "mengamankan" nilaininvestasi kita jika terjadi kerugian karena faktor risiko binis. Tegasnya bila kerugian yang timbul disebabkan karena faktor risiko bisnis, jaminan mudharib tidak dapat disita oleh shohibul maal

d. Menentukan Besarnya Nisbah, besarnya nisbah ditentukan berdasarkan kesepakatan masing-masing pihak yang berkontrak. Jadi, angka besaran nisbah ini muncul sebagi hasil tawar menawar antara shohibul maal dengan mudharib.

e. Cara Menyelesaikan Kerugian. Jika terjadi kerugian, cara menyelesaikannya adalah: Diambil terlebih dahulu dari keuntungan, karena keuntungan merupakan pelindung modal. Bila kerugian melebihi keuntungan, baru diambil dari pokok modal. 
Dalam dunia perbankan syariah, metode perhitungan bagi hasil dibedakan menjadi dua, yaitu:

\section{Metode profit sharing}

Profit sharing adalah perhitungan bagi hasil didasarkan kepada hasil bersih dari total pendapatan setelah dikurangi dengan biaya-biaya yang dikeluarkan untuk memperoleh pendapatan tersebut. Pada perbankan syariah istilah yang sering dipakai adalah profit and loss sharing, dimana hal ini dapat diartikan sebagai pembagian antara untung dan rugi dari pendapatan yang diterima atas hasil usaha yang telah dilakukan

2. Metode Revenue Sharing,

Revenue sharing secara bahasa berarti uang masuk, pendapatan atau income. Dalam istilah perbankan, revenue sharing berarti proses bagi pendapatan yang dilakukan sebelum memperhitungkan biaya-biaya operasional yang ditanggung oleh bank. Biasanya pendapatan yang didistribusikan hanyalah pendapatan atas investasi dana. Dana tidak termasuk fee atau komisi atas jasa-jasa yang diberikan oleh bank karena pendapatan tersebut pertama harus dialokasikan untuk mendukung biaya operasional bank.

\section{Sistem Mudharabah pada Perbankan Syariah}

Pembiayaan mudharabah merupakan akad pembiayaan antara bank syarih sebagai shahibul maal dan nasabah sebagai mudharib untuk melaksanakan kegiatan usaha dimana bank syariah memberikan modal sebanyak $100 \%$ dan nasabah menjalankan usahanya, Hasil usaha atas pembiayaan mudharbah akan dibagi antara bank syariah dan nasabah dengan nisbah bagi hasil yang telah disepakati pada saat akad.

Bank syariah memberikan pembiayaan mudharabah kepada nasabah atas dasar kepercayaan. Bank syariah percaya penuh kepada nasabah untuk menjalankan usaha. Kepercayaan merupakan unsur terpenting dalam transaksi pembiayaan mudharabah, karena dalam pembiayaan mudharabah,bank syariah tidak ikut campur dalam menjalankan proyek usaha nasabah yang telah diberi modal $100 \%$

Bank syariah hanya dapat memberikan saran tertentu kepada mudharib dalam menjalankan usahanya untuk memperoleh hasil usaha yang optimal. Dalam hal pengelolaan nasabah berhasil mendapatkan keuntungan, maka bank syariah akan memperoleh keuntungan 
dari bagi hasil yang diterima. Sebaiknya, dalam hal nasabah gagal menjalankan usahanya dan mengakibatkan kerugian, maka seluruh kerugian ditanggung oleh shahibul maal

Dalam perkembangannya pada praktik ekonomi modern dalam transaski mudharabah khususnya di Indonesia seorang mudharib akan dibebani dengan jaminan. Hal ini sebagaimana diatur dalam ketentuan Bank Indonesia sebagaimana yang dituangkan dalam peraturan Bank Indonesia No: 7/46/PDI/2005 Pasal 6 huruf (o) yang menjelaskan bahwa bank dapat meminta pinjaman atau agunan untuk mengatisipasi resiko apabila nasabah tidak dapat dikewajiban sebagaimana dimuat dalam akad karena kelalaian dan/kecurangan

Selain itu diwajibkannya jaminan dalam transaksi mudharabah juga terdapat dalam Fatwa Dewan Syariah Nasional No: 07/DSN-MUI/IF/2000 tentang pembiayaan mudharabah yang menyatakan bahwa pada prinsipnya, dalam pembiayaan mudharabah tidak ada jaminan, namun agar mudharib tidak melakukan penyimpangan Lemaba Keuangan Syariah dapat meminta jaminan dari mudharib atau pihak ketiga.

Diterapkannya jaminan dalam transaksi mudharabah didasarkan pada penerapan metode ijtihad yang tidak dalam maksud mengesampingkan dari hukum asalnya namun lebih didasarkan pada prinsip penggunaan metode istihsan. Metode ini pada prinsipnya mengutamakan tujuan untuk mewujudkan kemaslahatan-kemaslahatan atau menolak bahayabahaya secara khusus sebab dalil umum menghendaki dicegahnya bahaya itu.

\section{METODE PENELITIAN}

Dalam penelitian ini, penulis menggunakan pendekatan kualitatif deskriptif, dimana kajian yang dilakukan bersifat eksploratif melalui pengumpulan data. Penelitian ini juga bisa dikatakan sebagai library research atau penelitian literature. Penelitian ini dilakukan dengan mengumpulkan bahan pustaka yang relevan dengan topic penelitian yaitu pengaplikasian system pembiayaan mudharabah pada lembaga keuangan syariah khususnya perbankan syariah. Kemudian interpretasi data nantinya bisa di gambarkan dari hubungann antara data-data yang termuat dari hasil survey literature maupun dokumentasi

\section{HASIL DAN PEMBAHASAN}

\section{Implementasi Pembiayaan mudharabah sebagai Produk Perbankan Syariah}

Menurut Muhammad (2016) Mudharabah diartikan sebagai bentuk kerja sama antara pihak bank selaku pemilik dana dengan nasabah selaku pengelola dana yang 
mempunyai kemampuan dan keahlian untuk mengelola suatu usaha yang produktif dan halal, dimana keuntungan dari usaha tersebut dibagi sesuai dengan nisbah yang telah disepakati. Pada dasarnya pembiayaan dengan akad mudharabah cukup sederhana dan mudah untuk dipraktekkan pada perbankan syariah.

Untuk memahami akad mudharabah sebagai perwujudan dari profit and Loss Sharing (PLS), maka bank syariah wajib memberikan sumber pembiayaan yang luas kepada peminjam berdasarkan atas bagi resiko (baik menyangkut keuntungan maupun kerugian), yang berbeda dengan pembiayaan system bunga pada dunia perbankan konvensional yang semua resikonya ditanggung oleh pihak peminjam (Saeed, 2008). Dalam pembiayaan mudharabah dikenal dengan principal-agent adalah hubungan yang dimana principal mendelegasikan wewenang kepada agent dalam hal pengelolaan usaha sekaligus pengambil keputusan dalam perusahaan.

Hal ini menimbulkan kekhawatiran atas resiko yang mungkin bisa terjadi dimana pembiayaan yang telah diberikan kepada agent (mudharib) tidak dipergunakan sebagaimana mestinya untuk memaksimalkan keuntungan kedua belah pihak. Ketika dana dikelola oleh mudharib, maka akses informasi bank terhadap usaha mudharib menjadi terbatas. hal tersebut menimbulkan terjadinya asymmetric information dimana mudharib mengetahui informasi-informasi yang tidak diketaui oleh pihak bank (shahibul maal). Tarsidin (2010) berpendapat bahwa mudharib memiliki informasi privat tentang karakteristik dirinya, tingkat utilitas yang diinginkannya dan level upaya yang dilakukannya. Perlunya biaya yang besar untuk mendapatkan informasi tersebut sehingga tidak efisien bagi shahibul maal untuk berusaha mendapatkannya.

Selain itu, juga bisa memicu timbulnya moral hazard dari pihak agent dimana mudharib melakukan hal-hal yang bisa saja menguntungkan dirinya dan merugikan pihak bank (principal). Adanya perbedaaan kepentingan antara mudharib dan shahibul maal menyebabkan tingginya resiko dalam pembiayaan dengan akad mudharabah. Adapun cara untuk meminimalisir permasalahan terkait asymmetric information pada akad pembiayaan mudharabah maka pihak Bank Syariah selaku shahibul maal perlu membuat skema bagi hasil yang dapat memnuhi harapan kedua belah pihak.

Pada umumnya bentuk aplikasi pembiayaan mudharabah di perbankan syariah di mulai dari pihak nasabah sebagai calon mudharib mengajukan permohonan pembiayaan akad mudharabah pada bank syariah dengan melengkapi persyaratan yang diwajibkan oleh pihak bank syariah. Pihak bank syariah melakukan observasi lapangan tentang kebenaran 
keterangan yang diberikan oleh nasabah. Selanjutnya bank syariah melakukan musyawarah internal untuk memutuskan disetujui atau ditolak permohonan nasabah. Tentunya pihak bank akan menyetujui melakukan pembiayaan usaha tersebut jika tingkat keuntungan yang diharapkan cukup menjanjikan dan tingkat pengembalian modal sangat tinggi.

Berdasarkan proses pengaplikasian akad pembiayaan mudharabah yang telah dikemukakan sebelumnya itu pada dasarnya tidak mudah untuk dilakukan secara langsung karena pihak Bank Syariah sering terjadi permasalahan terkait adverse selection. Dalam hal ini pihak Bank Syariah mengalami kesulitan dalam mengetahui kemampuan dan karakter para nasabah dalam menjalankan usaha yang akan diberikan pembiayaan dengan akad mudharabah. Untuk mengatasi masalah tersebut, pihak Bank Syariah menerapkan standard analisis yang lebih ketat dalam hal peneyeleksian calon nasabah

Salah satu cara untuk mengetahui informasi yang akurat dari para calon nasabah kepada pihak bank sebagai shahibul mall, maka Bank Syariah harus mengeluarkan biaya verifikasi yang tinggi untuk memeriksa dan mendapatkan kebenaran mengenai informasi calon nasabah. Tapi ini juga menjadi pertimbangan pihak Bank Syariah karena harus mengeluarkan biaya tambahan terkait biaya verifikasi yang kemungkinan nominalnya yang tinggi.

\section{Upaya-upaya Pengendalian Resiko Pembiayaan Mudharabah}

Adnan dan Didi (2013) menjelaskan bahwa pembiayaan mudharabah dikatakan ideal karena memiliki peran dala perkembangan pemberdayaan Ekonoi Islam yang sangat vital. Skema Akad pembiayaan mudharabah mentikberatkan pada keadilan, keseimbangan, dan menekankan pada hasil kerja serta resiko yang dihadapi. Namun karena dengan tingginya resiko dari pembiayaan mudharabah sehingga menyebabkan tingkat pengaplikasiannya di Bank Syariah atapun lembaga keuangan syariah lainnya sangatlah kurang dibandingkan dengan akad pembiayaan murabahah (jual beli).

Hal ini disebabkan karena akad murabahah itu sudah menunjukkan besarnya tingkat keuntungan yang akan diperoleh pada saat akad, sementara resiko yang mungkin terjadi juga relatif sedikit. Berbeda dengan pembiayaan mudharabah yang memiliki resioko yang itnggi disebabkan pihak bank menyerahkan modal kerja tidak disertakan dengan jaminan. Untuk itu, pihak perbankan syariah sebagai shahibul maal harus benar-benar teliti dalam hal memilih mudharib yang akan diberikan pembiayaan atau modal kerja. 
Untuk mengurangi permasalahan-permasalahan yang terjadi dalam akad pembiayaan mudharabah pada perbankan syariah, pemelik dana diharapakan membuat skema pembagian bagi hasil yang dapat menekan permasalahan asymmetric information. Maka Perbankan Syariah sebagai shahibul maal harus mengupayakan skema bagi hasil sesuai dengan harapan kedua belah pihak yang akan melakukan akad mudharabah. Dalam hal ini yang dimaksud adalah skema bagi hasil yang pada dasarnya dapat meminimalisir permasalahan adverse selection dan moral hazard.

Skema bagi hasil yang ditetapkan Perbankan Syariah diharapakan mampu mengungkapkan karakter calon nasabah yang jujur, dan upaya serta kerja keras yang dilakukan mudharib mampu meningkatkan profit secara maksimal yang nantinya juga akan dirasakan oleh pihak bank terkait dengan bagi hasil yang besar dari keuntungan yang dihasilkan. Perlunya keadilan dalam membuat rasio bagi hasil antara kedua belah pihak nantinya akan mendorong level upaya meminimalkan risiko terjadinya penyipangan dalam melaporkan pendapatannya. Pengungkapan karakter nasabah dan level upaya yang maksimal naninya akan dapat menekan biaya pengawasan dan verifikasi yang harus dikeluarkan dalam kontrak mudharabah, sehingga keuntungan yang akan dibagi nantinya juga akan meningkat.

Menurut Friyanto (2013) ada beberapa langkah dan upaya yang bisa dilakukan dalam upaya pemecahan masalah resiko penerapan pembiayaan mudharabah yaitu:

1. Menetapkan nilai maksimal rasio hutang terhadap modal, apabila jumlah modal mudharib dalam suatu usaha relatif tinggi maka kemungkinan untuk berlaku tidak jujur akan berkurang secara signifikan, karena muhdarib juga akan menanggung kerugian tas tindakannya tersebut.

2. Menetapkan perjanjian diadakannya monitoring, pihak Perbankan Syariah herus mengupayakan pengawasan atau monitoring baik itu pengawasan terkait usaha yang dijalankan oleh mudharib serta transparansi laporan keuangan (arus kas) yang dibuat. Salah satu tujuan dari monitoring aspek keuangan adalah untuk mengetahui kondisi usaha secara financial, menentukan jumlah pembiayaan yang wajar dan pantas serta kemapuan nasabah untuk mengembalikan dana yang diambil.

3. Menetapkan pembagian bagi hasil dengan sistem revenue sharing, perhitungan pembagian bagi hasil usaha dengan pendekatan revenue sharing akan lebih mudah karena hal ini akan sangat membantu pihak perbankan syariah untuk tidak 
memerlukan petugas yang memiliki keahlian khusus untuk mengontrol biayabiaya yang dikeluarkan oleh nasabah.

Berdasarkan uraian diatas terkait upaya pengendalian resiko skema pembiayaan mudharabah diharapkan dapat menjadi bahan perhatian pihak perbankan syariah dan lembaga keuangan syariah lainnya, karena pembiayaan mudharabah merupakan pembiayaan yang ideal dimana pihak shahibul maal dan mudharib merasa adil oleh suatu hasil yang diperoleh dalam menjalankan usaha atas dasar kesepakatan bersama.

\section{PENUTUP}

Pembiayaan mudharabah merupakan pembiayaan yang ideal dan menjadi salah satu icon alasan terbentuknya lembaga keuangan syariah terkhusus Perbankan Syariah. Dengan skema pembiayaan mudharabah yang ada di Perbankan Syariah diharapkan dapat menjadi solusi untuk menghilangkan prinsip bunga seperti yang diterapkan di perbankan konvensional. Tapi pada kenyataannya samapai saat ini pembiayaan dengan prinsip bagi hasil atau mudharabah ini sedikit kehilangan "eksistensinya" dalam porsi jenis pembiayaan yang disediakan oleh pihak perbankan syariah. Hal ini disebabkan ada akad pembiayaan lain seperti akad jual beli atau dikenal dengan istilah murabahah yang lebih menguntungkan para pihak dengan tingkat resiko yang cukup rendah.

Upaya-upaya yang bisa dilakukan untuk mengurangi resiko dan mengoptimlakan porsi akad pembiayaan mudharabah ini yaitu pihak perbankan syariah selaku shahibul maal melakukan pengawasan (monitoring) dan nasabah (mudharib) harus melakukan pembatasan atas tindakan-tindakannya dalam pemgelolaan usaha yang dikerjakan. Selain itu, diperlukan juga adanya garansi atau jaminan berupa fixed asset dan menetapkan rasio maksimal biaya operasional serta pembagian keuntungan berdasarkan profit and loss sharing.

Diharapkan untuk kedepannya, akad pembiayaan mudharabah tetap bisa menjadi primadona pada perbankan syariah dan lembaga keuangan syariah lainnya karena akad mudharabah sangat bermanfaat bagi kegiatan bisnis jika dapat dikelola dan dijalankan dengan baik serta dengan pengelolaan resiko yang tepat. 


\section{DAFTAR PUSTAKA}

Alma, Buchari. 2019. Manajemen Bisnis Syariah. Bandung: Alfabeth.

Ambarwati, S. 2008. Faktor-faktor yang Memengaruhi Pembiayaan Murabahah dan Mudharabah pada Bank Umum Syariah, Tesis, Program Pascasarjana Universitas Indonesia

Antonio, M.S. 2001. Bank Syariah : dari Teori ke Praktek, Jakarta : Gema Insani Pres

Aziz,A. 2010. Manajemen Investasi Syariah. Bandung: Alfabeth.

Dewi, Ernanda Kusuma dan Ayu Astari. Peran Pembiayaan Mudharabah Dalam Pengembangan Kinerja Usaha Mikro Pada BMT (Baitul all Wat Tamwil). JUrnal Law and Justice Vol. 2 No. 2 Oktober 2017.

Friyanto. Pembiayaan Mudharabah, Resiko dan Penannganannya (Studi Kasus pada Bank BTN Kantor Cabang Syariah Malang). Jurnal Manajemen dan Kewirausahaan Vol. 15 No. 22013.

Karim, A. 2010. Bank Islam: Analisis Fiqih dan Keuangan. Jakarta : Kencana.

Kettel, B. 2011. Introduction to Islamic Banking and Finance. United Kingdom : Print House Northamton.

Muhammad. 2015. Konstruksi Mudharabah Dalam Bisnis Syariah. Yogyakarta : BPFE Yogyakarta.

Qomar, Muh. Nurul. Mudharabah Sebagai Produk Pembiayaan Perbankan Syariah Perspektif Abdullah Saeed. MALIA: Jurnal of Islamic Banking and Finance Vol.2 No.2 2018.

Sa'diyah, Mahmudatus, dan Meuthiya Athiya,Arifin. Udharabah dalam Fiqih dan Pernankan Syariah. Jurnal Aquilibrium Vol. 1 No. 2 Desember 2013, 302-323.

Saeed, Abdullah. 2008. Bank Islam dan BUnga; Studi Kritis dan Interpretasi Kontemporerbtentang Riba dan Bunga. Yogyakarta : Pustaka Pelajar

Sarono, Agus. Analisis Problem Pebiayaan Mudharabah Serta Solusinya. Diponegoro Private Law Riview Vol. 4 No. 1 Februari 2019.

Suhendi,H. 2011. Fiqih Muamalah. Jakarta: Kencana.

Tarsidin. 2010. Bagi Hasil : Konsep dan Analisis. Jakarta : Lebaga Penerbit Fakultas Ekonomi.

Waluyo, Bambang. Implementasi Pembiayaan Mudharabah pada Bank Syariah untuk Merealisasikan Tujuan Ekonomi islam Jurnal Ekonomi dan Bisnis Islam Vol. 2 No. 22016.

Yuliana, I. 2010. Investasi Produk Keuangan Syariah. Malang: UIN-MALIKI PRESS. 